\title{
FORMUŁA LOKALIZACYJNO-TEMPORALNA W TEKSTACH EPISTOLARNYCH XVIII WIEKU
}

\author{
Katarzyna Sicińska \\ Uniwersytet Łódzki \\ ORCID: 0000-0003-4080-1497
}

\begin{abstract}
Streszczenie. Przedmiotem opisu jest formuła lokalizacyjno-temporalna, informująca o miejscu i czasie napisania listu, występująca w korespondencji przedstawicieli stanu szlacheckiego w XVIII wieku. W artykule przedstawione zostały różne formy realizacyjne formuły, to znaczy jej pozycja w strukturze listu, zawartość treściowa, a przede wszystkim sposób zapisu głównych komponentów formuły, czyli toponimu wskazującego miejsce napisania listu (zazwyczaj występuje on w postaci wyrażenia przyimkowego w miejscowniku z przyimkiem $w$ lub $z$ ), oraz daty (w tym zakresie zaznacza się silny wpływ języka łacińskiego). Omówione też zostały liczne funkcje formuły lokalizacyjno-temporalnej, takie jak określanie sytuacji komunikacyjnej, tworzenie wspólnoty czasowo-przestrzennej nadawcy i odbiorcy, wyznaczanie granic tekstu i inne.
\end{abstract}

Słowa klucze: epistolografia, formuła lokalizacyjno-temporalna, delimitacja tekstu, język polski XVIII wieku

Jednym z obligatoryjnych komponentów osiemnastowiecznego tekstu epistolarnego była formuła lokalizacyjno-temporalna, informująca o miejscu i czasie napisania listu. Należy ona zresztą do stałych i ponadczasowych elementów struktury listu ${ }^{1}$. W komunikacji epistolarnej będącej komunikacją pośrednią, na odległość, przebiegającą w warunkach znacznego niekiedy dystansu przestrzennego i czasowego między rozmówcami, obecność tejże formuły jest nieodzowna ${ }^{2}$. Osadza ona bowiem nadawcę w konkretnym miejscu i czasie, przez co przybliża realia sytuacji komunikacyjnej ${ }^{3}$, a tym samym

Zob. K. Data, Struktura tekstu listowego, „Język Polski” 69, 1989, z. 3-5, s. 142-152; A. Kałkowska, Struktura składniowa listu, Wrocław 1982; M. Olma, Listy emigracyjne Józefa Ignacego Kraszewskiego do Władysława Chodźkiewicza. Analiza pragmalingwistyczna, Kraków 2006, s. 123-124; E. Książek, Tekst epistolarny w świetle etykiety językowej, Kraków 2008, s. 32-41.

Na temat istoty listu jako gatunku zob. A. Całek, Nowa teoria listu, Kraków 2019.

Przez sytuację komunikacyjną rozumiem zespół okoliczności towarzyszących wypowiedzi, stanowiących dla niej ramę zewnętrzną (zob. U. Żydek-Bednarczuk, Wprowadzenie do lingwistycznej analizy tekstu, Kraków 2005, s. 231). 
umożliwia w ogóle porozumienie pomiędzy interlokutorami. Obecność elementów faktograficznych buduje ponadto wiarygodność tekstu epistolarnego, wiarygodność rzeczywistości przedstawionej w liście ${ }^{4}$.

Formuła lokalizacyjno-temporalna odgrywa też inną ważną rolę w liście. W komunikacji epistolarnej mamy do czynienia z trzema płaszczyznami czasowymi: czas pisania - czas relacjonowanych zdarzeń - czas odbiorus. To, co się dzieje w otoczeniu nadawcy i o czym ten nadawca pisze, jest odległe dla odbiorcy. Z kolei świat odbiorcy i czas odbioru przez niego listu jest niedostępny nadawcy. A zatem jedynym wspólnym uniwersum, wokół którego można zorganizować komunikat, jest „tu” i ,teraz” aktu pisania. Owo „tu” i „teraz” wskazane w formule spacjalno-temporalnej wyznacza zatem pewną wspólnotę czasową i przestrzenną, sytuuje nadawcę i odbiorcę w jednej rzeczywistości, tworzy zastany układ odniesienia stanowiący podstawę porozumienia ${ }^{6}$.

Wspomniane walory i funkcje formuły spacjalno-temporalnej odgrywały, jak można sądzić, niebagatelną i znacznie poważniejszą niż dziś rolę w korespondencji doby średniopolskiej, w tym osiemnastowiecznej. Listy stanowiły wówczas podstawowy środek komunikacji społecznej, podstawowe medium informacyjne, w związku z czym istotne znaczenie miało zachowywanie ciągłości i regularności korespondencji. Nie było to łatwe w sytuacji dużej mobilności szlachty ${ }^{7}$ oraz długiego procesu przesyłania listu ${ }^{8}$. Informacja o tym, kiedy i skąd list został nadany, miała w tych okolicznościach ogromne znaczenie, ponieważ wskazywała wprost na aktualne (lub niedawne) miejsce pobytu nadawcy, pośrednio sugerowała też adres zwrotny (choć do zwyczaju epoki należało informowanie adresata, dokąd osoba pisząca list zamierza się wkrótce udać albo dokąd adresować kolejne listy ${ }^{9}$ ), a poza tym wpisywała

\footnotetext{
4 E. Książek, op. cit., s. 34; por. S. Skwarczyńska, Teoria listu, oprac. E. Feliksiak, M. Leś, Białystok 2006.

$5 \quad$ M. Wołk, Tekst w dwóch kontekstach. Narracja pierwszoosobowa w powieściach Kazimierza Brandysa, Toruń 1999, s. 150; cyt. za E. Książek, op. cit., s. 34.

6 E. Książek, op. cit., s. 34; J. Lalewicz, Komunikacja językowa i literatura, Wrocław 1975, s. 18 .

Owa mobilność wynikała z przemieszczania się przedstawicieli szlachty pomiędzy majątkami, odbywania podróży związanych z wypełnianiem obowiązków urzędowych i politycznych oraz z uczestnictwa w działaniach wojennych.

W XVIII wieku istniała już w Polsce sieć sprawnie działających linii pocztowych zagranicznych i krajowych (także na obszarze Litwy), choć oczywiście szybkość przekazywania informacji była inna niż współcześnie. Zob. J. Pirożyński, $Z$ dziejów obiegu informacji w Europie XVI wieku. Nowiny z Polski w kolekcji Jana Jakuba Wicka w Zurychu z lat 1560-1587, „Zeszyty Naukowe UJ”, Prace Historyczne, z. 115, 1995, s. 91; K. Maliszewski, Komunikacja społeczna w kulturze staropolskiej. Studia z dziejów ksztattowania się form i treści społecznego przekazu w Rzeczypospolitej szlacheckiej, Torun 2001, s. 30-34.

9 Przykładowo: „Czekam na poczte Lubelsko y Włodzimirsko na Wołyniu pomyslnych od JOW[X]Mci Dobrodzieja rezolucyi” CzacSz4, 9. Szerzej na ten temat zob. K. Sicińska, , Pisa-
} 
dany tekst w ciąg korespondencji między stałymi uczestnikami dialogu epistolarnego.

Należy także zwrócić uwagę na to, że elementy faktograficzne zawarte w formule spacjalno-temporalnej stanowią ważny wyróżnik gatunkowy tekstu epistolarnego. Zdaniem Elżbiety Książek formuła ta, obok formuły inicjalnej i finalnej, stanowi ,przedlekturowy sygnał gatunkowości”"10, swego rodzaju znak rozpoznawczy pozwalający na wstępną kwalifikację gatunkową. Informacja o miejscu i czasie nadania listu to nie tylko suche dane, to element konwencji gatunkowej ${ }^{11}$. Tym samym formuła spacjalno-temporalna wpisuje się w kanon typowych i skonwencjonalizowanych formuł dawnej epistolografii ${ }^{12}$.

Formuła lokalizacyjno-temporalna spełnia zatem istotne i różnorodne funkcje w tekście epistolarnym: 1) utrwala sytuację czasoprzestrzenną listu jako komunikatu, umożliwiając porozumienie między nadawcą a odbiorcą, 2) buduje wiarygodność tekstu epistolarnego jako komunikatu, 3) tworzy płaszczyznę wspólnoty nadawcy i odbiorcy, 4) sytuuje pojedynczy tekst epistolarny w ciągu korespondencyjnym, 5) ewokuje jego przynależność gatunkową. To jej wielorakie obciążenie funkcjonalne w połączeniu z metatekstowym charakterem (odnosi się ona do okoliczności powstawania listu) oraz granicznym, a przez to strategicznym usytuowaniem (początek lub zakończenie listu) sprawia, że stanowi ona jeden z zasadniczych wykładników delimitacji tekstu, a więc wyznaczników granic tekstu, oddzielających tekst od kontekstu. Jest też w zasadzie obligatoryjnym, nieredukowalnym składnikiem listu.

nie”, , ,litera”, ,gramota”... O nazwach listu w polszczyźnie XVII i XVIII wieku, [w:] W kręgu dawnej polszczyzny, t. 2, red. M. Mączyński, E. Horyń, E. Zmuda, Kraków 2016, s. 263-286.

10 Termin stosowany przez Wołka (M. Wołk, op. cit., s. 28). Cyt. za E. Książek, op. cit., s. 34.

11 E. Książek, op. cit., s. 34.

12 Szczególna kumulacja konstrukcji formulicznych występowała w partiach inicjalnych i finalnych listów. Ich zadaniem było inicjowanie bądź wygaszanie kontaktu między uczestnikami komunikacji, tworzenie lub podtrzymywanie atmosfery uprzejmości między uczestnikami komunikacji oraz sygnalizowanie granic tekstu. Zob. K. Mroczek, Tytulatura w korespondencji staropolskiej jako problem stosunku między nadawca a odbiorca, ,Pamiętnik Literacki” 69, 1978, z. 2, s. 127-148; M. Cybulski, Obyczaje językowe dawnych Polaków. Formuly werbalne w dobie średniopolskiej, Łódź 2003; K. Sicińska, Formuły salutacyjne w korespondencji z terenu Kresów Poludniowo-Wschodnich (XVII-XVIII wiek), [w:] Zachowanie językowe - spontaniczność i automatyzm, red. M. Hawrysz, M. Uździcka, A. Wojciechowska, Zielona Góra 2017 („Zielonogórskie Seminaria Językoznawcze" 2016), s. 225-249; eadem, Formuly subskrypcji w korespondencji z terenu Kresów Poludniowo-Wschodnich (XVII-XVIII wiek), cz. 1, [w:] Epistolografia w dawnej Rzeczypospolitej, t. 7: Literatura, historia, język, red. P. Borek, M. Olma, Kraków 2017, s. $277-$ 298; eadem, Formuła wyrażania szacunku w strukturze osiemnastowiecznego listu polskiego, „LingVaria” 14 (2019), nr 2 (28), s. 107-119; eadem, Wierność, powinność, uniżoność i inne kategorie grzeczności językowej w finalnych formułach epistolarnych XVIII wieku, „Poznańskie Studia Polonistyczne. Seria Językoznawcza” 2020, t. 27 (47), nr 1, s. 163-183; DOI: 10.14746/ pspsj.2020.27.1.11; https://pressto.amu.edu.pl/index.php/pspsj/article/view/24583. 
Pomimo uwarunkowanego faktograficznością schematyzmu formuła spacjalno-temporalna przybierała $\mathrm{w}$ listach osiemnastowiecznych dość zróżnicowane formy realizacyjne. Różne bywało jej usytuowanie w strukturze tekstu, różnie przedstawiała się jej zawartość informacyjna, niejednolity bywał sposób zapisu danych. Na pewno odbiegała też w swojej postaci od współcześnie stosowanej formuły. Przedstawione poniżej ustalenia oparte są na analizie 305 oryginalnych, rękopiśmiennych listów z XVIII wieku, pisanych przez kilkudziesięciu (dokładnie 47) autorów pochodzenia szlacheckiego ${ }^{13}$.

\section{USYTUOWANIE FORMUŁY LOKALIZACYJNO-TEMPORALNEJ}

W listach osiemnastowiecznych formuła lokalizacyjno-temporalna umieszczana była najczęściej na końcu listu, w lewym dolnym rogu kartki, i przybierała postać typu: $w$ Lwowie <die> 22 Januarij $1758^{\circ}$ AugJS4, 7, $<$ die $>15$ 8bris 1735 w Lublinie BorW3, 6, przy czym zapis ten często rozbijany był na dwie linijki (np. data i nazwa miejsca w osobnych linijkach albo tylko data roczna przeniesiona do drugiej linijki). Finalne ulokowanie formuły wynikało prawdopodobnie z faktu, iż moment rozpoczęcia listu i moment jego ukończenia dzielił niekiedy spory dystans czasowy. W trakcie pisania mogły zajść wydarzenia, o których wzmiankowano następnie w treści listu, a zatem najwygodniej i najpraktyczniej było utrwalić informację o miejscu i czasie nadania dopiero w momencie faktycznego zakończenia procesu tworzenia tekstu, a więc umieścić ją w końcowym fragmencie listu.

Nawet jeśli formuła mieściła się w zakończeniu listu, nie zawsze stanowiła jego rzeczywisty element finalny. Bywało, że poniżej formuły, wokół niej, a nawet ponad nią piszący zamieszczał jeszcze różnorodne dopiski końcowe o charakterze postscriptum. Na pewno jednak formułę sytuowano po tekście głównym.

Znacznie rzadziej informacja o miejscu i czasie nadania listu znajdowała się w badanej korespondencji na początku listu, w prawym górnym rogu kartki, czyli zgodnie z dzisiejszym zwyczajem. Pod względem struktury nie różniła się od tej formuły, którą lokowano w zakończeniu listu, częściej jedynie zapisywana była wówczas w jednym wersie, np. Z Maykowa $<$ die $>10$ Septembris 1737 CzetwGab2, w Czemiernikach $<$ die $>30$ 8bris 1712 HumS5, 28, z Brzezan 2da feb 1706 PotJ2, 16.

\footnotetext{
13 Listy te były przedmiotem mojego opisu w zakresie reprezentacji regionalnych cech południowokresowych (K. Sicińska, Polszczyzna poludniowokresowa XVII i XVIII wieku (na podstawie epistolografii), Łódź 2013). W tej też monografii znajduje się ich całościowy wykaz oraz system lokalizatorów źródłowych, przeniesionych do niniejszego artykułu. Autorami listów były osoby wywodzące się z terenu dawnych Kresów Południowo-Wschodnich.
} 
Współcześnie obligatoryjną w zasadzie pozycją formuły spacjalno-temporalnej jest pozycja inicjalna, do rzadkości należy jej usytuowanie w pozycji finalnej. W stosunku do stanu osiemnastowiecznego nastąpiło więc odwrócenie sytuacji. Takie zmiany w pozycji elementów kompozycyjnych listu obserwuje się w całej historii epistolografii, np. subskrypcja, czyli podpis nadawcy, od średniowiecza aż po dziś umieszczana zwyczajowo w zakończeniu listu, w czasach starożytnych znajdowała się we wstępnej części tekstu epistolarnego, jako tzw. petitio, czyli 'nadpis'"14.

Warto na koniec dodać, że zdarzają się też niekiedy listy pozbawione formuły spacjalno-temporalnej (np. ŁaszAM10; ŁaszJA4; PotJ10; PotJoach10).

\section{ZAWARTOŚĆ INFORMACYJNA FORMUŁY LOKALIZACYJNO-TEMPORALNEJ}

Podstawową funkcją formuły lokalizacyjno-temporalnej jest przekazanie informacji o miejscu i czasie napisania listu. Ten ściśle faktograficzny charakter formuły narzuca jej szablonową, mało podatną na innowacje strukturę formalną. W skład formuły musi bowiem wchodzić nazwa miejscowości oraz dokładna data określająca dzień, miesiąc i rok napisania listu. W szczegółach jednak zapis ten przedstawia się w badanych listach dość różnorodnie. Już sama kolejność podawania informacji bywa różna: na pierwszym miejscu może się znajdować albo wskazanie miejsca, jak np. $\boldsymbol{w}$ Lwowie $<$ die $>22 \mathrm{Ja}$ nuarij $1758^{\circ}$ AugJS4, 7, Z Lublina $<$ die $>$ Ima Novembris $1735 A^{\circ}$ BorW4, 8, z Lasczowa 28 Mai 1744 ŁaszJA5, 121, albo określenie czasu, np. $1763<$ die> 13 Augusti $z$ Lublina BejzP2, 5, <die> 22 Iuny 1763 W Porycku CzasSz2, 6, 1 Augusti 1777 W Porycku CzacSz8.

Niekiedy formuła poprzedzana jest łacińskim słowem datum 'dane', zapisywanym w skrócie Dat., Datt. lub nawet D.: Dat: 5: January: 1710 BorW1, 2, Datt z Holuzyi <die> 287 bris 1765 a KonAD1, 3, Datt 30 May 1777. w Lwowie PotIg6, D. 11 8bri R 1764 WorJad9, 97, D. 29. Febr: 1776 Warszawa RzewSJ1. Owo łacińskie datum to metatekstowe określenie, które jednoznacznie identyfikuje formułę faktograficzną wyznaczającą czasoprzestrzeń sytuacji komunikacyjnej.

Zdarzają się też formuły niepełne informacyjnie, mianowicie pozbawione identyfikacji miejsca: Dat: 5: January: 1710 BorW1, 2, <die > 20. Aprilis 1720 ŁaszJA1, 6, <die> 31 Augusti 1736 CzetwGab1, <die> 12. January $1776 A^{\circ}$ LipKJ4, 78v, <die $>22$. Iuly $1776 a^{\circ}$ LipKJ5, 28 Juny 1752 PotFS10, 51, 26 Augusti 1710 PotStan1, <die> 12 Aprilis 1755 WorJA1, 46. Brak lokalizacji przestrzennej obserwuje się w przypadku regularnej korespondencji pomiędzy danymi osobami, np. pomiędzy członkami rodziny (przykładowo

14 S. Skwarczyńska, op. cit., s. 239, 241, 253. 
formuła $<$ die $>12$ Aprilis 1755 pochodzi z listu Jakuba Anastazego Woronicza do ojca). Znaczna częstotliwość oraz systematyczność przesyłania listów usprawiedliwia pomijanie przez nadawcę powtarzalnej i znanej odbiorcy informacji. Bywa też tak, że konkretyzacja miejsca pojawia się metatekstowo w głównej części listu, co również w jakimś stopniu tłumaczy brak tego typu informacji w formule granicznej. Najwyraźniej też pełny skład formuły lokalizacyjno-temporalnej nie był wskaźnikiem stopnia grzeczności w relacjach między partnerami komunikacji, skoro takie zredukowane do samej datacji warianty formuły mogły wystąpić w liście do monarchy, np. w listach Kazimierza Józefa Lipińskiego do króla Stanisława Augusta Poniatowskiego (zob. powyżej <die $>12$. January $1776 A^{\circ} \mathrm{i}<$ die $>22$. Iuly $1776 a^{\circ}$ ).

Temporalny wymiar sytuacji komunikacyjnej może być z kolei wzbogacony o dodatkowe, ponadstandardowe szczegóły faktograficzne, jak np. określenie pory dnia czy nawet godziny: $1752<$ die $>22$ aprilis z Samczykow o godzinie drugiey s poludnia ChojFK1, 5, 14 aprilis 1752 przed poludniem PotFS7, 25. Takie deskryptywne uszczegółowienia dające dokładny wgląd w okoliczności powstania listu służą określonemu celowi. Na przykład autor listu, z którego pochodzi ostatni przykład, Franciszek Salezy Potocki, pisze w zakończeniu: „Wczora list odebrany Z ukrainy mam honor odesłac JWW Panu Dobrodziejowi [...]. Namieniłem azeby Przykazał IP Oszga aby rozstawiona poczta spieszniey szła bo y ten list dni Iedynascie tu szedł, do krystynopola" PotFS7, 25. Nadawca dołączył do swojego listu inny list, dotyczący ważnych wydarzeń politycznych w Polsce, dlatego zależało mu na szybkim (jak na ówczesne możliwości) przebiegu korespondencji. W tym celu podjął szczególne działania (rozkaz pospiesznego doręczenia poczty wydany osobom przewożącym korespondencję). Zapewne ze względu na ów pożądany pośpiech sygnalizował nawet porę nadania listu. Przytoczony fragment wyjaśnia też, dlaczego formuła zawiera jedynie datę bez nazwy miejscowości - nazwa ta pada w tekście głównym listu, a w połączniu z zaimkiem deiktycznym $t u(t u$, do Krystynopola) jednoznacznie wskazuje na miejsce nadania listu.

\section{STRUKTURA FORMALNO-SEMANTYCZNA FORMUŁY LOKALIZACYJNO- TEMPORALNEJ}

Miejsce nadania listu sygnalizowane jest nazwą miejscowości. Toponim występuje w analizowanych listach najczęściej w postaci wyrażenia przyimkowego w miejscowniku:

- albo z przyimkiem $w$, jako wyrażenie odpowiadające na pytanie: gdzie napisane?, np. w Buczaczu 24 Febr: 1745 PotMB1, 2, w Czortkowie <die> 24 9bris 1754. PotJoach6, 11, w Knerucie $1737<$ die> 1 Martij BorW5, 11, 13 kwietnia 1752 w krystynopolu PotFS6, w Lwowie $<$ die> 22 Januarij $1758^{\circ}$ 
AugJS4, 7, we Lwowie <die> 13 xbris 1753 PotJoach4, 8, w Laszczowie 12 Xbris 1708 ŁaszAM3, 12 xbris 1764 w Porycku CzacSz6, 51, <die> 26. Marty 1737 w Zulkwi PotJóz5;

- albo z przyimkiem $z$, jako wyrażenie odpowiadające na pytanie skad napisane (skad wystane)?, np. <die> 18 Maja 75 z Buczacza PotIg5, 7, z gotogur 16 May 1706 PotJ3, 23, Z Lublina $<$ die $>1$ ma Novembris $1735 A^{\circ}$ BorW4, 8, Z Samczykow $1752<$ die> 14 Marty ChojFK2, 43v.

W regularnej korespondencji pomiędzy tymi samymi osobami nazwa miejscowości bywała niekiedy skracana, zwłaszcza gdy była to nazwa głównej czy rodowej siedziby nadawcy. Przykładem może być korespondencja Szczęsnego Czackiego, którego dobra dziedziczne stanowił m.in. Poryck i Brusiłów: 7 ap 1779 w Por $<$ ycku $>$ CzacSz9, 31 May 83 w Brusil $<$ owie> CzacSz10, korespondencja Kazimierza Józefa Lipińskiego, który wprawdzie wywodził się z Mazowsza, ale mieszkał i działał intensywnie na Podolu, a do jego majątku należał m.in. Żwańczyk: <die> $258 b r 1772 a^{0}$ z Z wan<czyka $>$ LipKJ1, 63, <die $>$ 8. Iuny $82 a^{\circ}$ z Zwan $<$ czyka $>$ LipKJ6, korespondencja Aleksandra Michała Łaszcza Tuczapskiego z Łaszczowa: 13 Ianu: 1717 w Lascz $<$ owie> ŁaszAM7, 117v czy też listy Seweryna Józefa Rzewuskiego z rodu Rzewuskich herbu Krzywda, właścicieli Podhorców: <die>29 Julii 1777 w Podh $<$ orcach $>$ RzewSJ4. Skróceniu ulegały też nazwy dużych miast, w których akurat przebywali nadawcy listów, np. Lublina: 3 July 1712 w Lubli< nie $>$ PotStefI4, 25 czy Warszawy: $\boldsymbol{w}$ warszaw: $<\mathrm{ie}>5$ 8bris 1723 PotJóz4, 66. Fakt skrócenia nazwy z rzadka tylko bywał sygnalizowany dwukropkiem lub tyldą, z reguły nie był oznaczany w żaden sposób, co pozostawało w zgodzie w ogólną tendencją w zakresie oznaczania skrótów w tej epoce ${ }^{15}$.

Niekiedy nazwa miejscowości bywała dookreślana przez wskazanie sąsiedztwa innej większej miejscowości, np. W Dubie pod Zamosciem <die> 12 Iuny 1733 HumS7, 37v.

W korespondencji osób wykształconych, takich jak wysocy dostojnicy kościelni, pojawiały się łacińskie odpowiedniki nazw miejscowości, np. w listach Jakuba Stefana Augustynowicza, arcybiskupa lwowskiego obrządku ormiańskiego: Leopoli <die> 11 Xbris 1747 AugJS1, 2, Leopoli <die> 10 July 1757 AugJS3, 5 (łac. Leopoli ‘we Lwowie' od Leopolis 'Lwów').

Do rzadkości należą formuły, w których toponim użyty jest w mianowniku: <die> 28 Listopada $R^{\mathrm{u}} 92$ Zwańczyk LipA, 123, D. 29. Febr: 1776 Warszawa RzewSJ1.

Korespondencja stanowiąca podstawę analizy to listy pisane przez autorów pochodzących $\mathrm{z}$ dawnych Kresów Południowo-Wschodnich, a toponimy zawarte $\mathrm{w}$ analizowanych formułach potwierdzają zasięg geograficzny bada-

15 Zob. m.in. K. Sicińska, Polszczyzna poludniowokresowa XVII i XVIII wieku (na podstawie epistolografii), s. 106-107. 
nej epistolografii. Są to bowiem takie miejscowości, jak m.in.: Bakuńczyce, Borszczowice, Brzeżany, Buczacz, Czortków, Derewlany, Gołogóry, Hołoby, Hołuzja, Hulowiec, Kałuszów, Kaszyce, Kneruty, Krystynopol (dziś Czerwonogród), Kustyń, Lublin, Lwów, Łaszczów, Pilawce, Podhorce, Poryck, Trojanów, Udnów, Winnica, Żółkiew, Żwańczyk, Żytomierz ${ }^{16}$. Występują też inne nazwy miejscowości, wskazujące na kierunki podróżowania autorów listów, np. Warszawa, Preszów.

Drugi obligatoryjny składnik formuły to informacja o czasie napisania listu. Kształt tej części formuły odzwierciedla dawne zwyczaje datacyjne. Mamy tu różne schematy formalne:

1) dzień, miesiąc, rok: 1 Augusti 1777 W Porycku CzacSz8, w Bakunczycach 3 July 1700 ŁaszAM1, 4;

2) dnia + dzień, miesiąc, rok: Dnia 13 Grudnia 1769 z Preszowa PotIg2, 2 (bardzo rzadki model);

3) die 'w dniu' + dzień, miesiąc, rok: $w$ Lwowie die 12 Xbris 1759 AugJS6, 9, < die> 21 Xbris 1763 w Porycku CzacSz5;

4) die 'w dniu' + dzień, miesiąc + anno 'w roku' + rok: <die > 26. Maji Anno 1770 z Hołuzyi KonAd;

5) die 'w dniu' + dzień, miesiąc, rok + anno 'w roku': <die> 20 Iuny 1767 Ao z Zytomierza NiemM;

6) anno 'w roku' + rok + die 'w dniu' + dzień, miesiąc: $A^{\circ} 1753<$ die $>26$ februarij CzetwM4, 8;

7) rok + die 'w dniu' + dzień, miesiąc: Datt. Z Kaszogrodu $1776<$ die> 27 8bris StecJ2, 3.

Dominuje datacja oparta na schemacie od jednostki najmniejszej do największej, czyli dzień, miesiąc, rok (typy 1-5). Schemat odwrotny występuje rzadko (typy 6-7).

Należy się teraz przyjrzeć dokładniej sposobom oznaczania poszczególnych danych czasowych.

Datę dzienną poprzedza najczęściej łaciński wyraz die 'w dniu' (od łac. dies 'dzień', diei 'dnia'), zapisywany z reguły za pomocą skrótu $d$ oraz tyldy. Niezwykle rzadko pojawia się zamiast niego polskie określenie dnia.

Dzień miesiąca oznaczany jest za pomocą cyfry arabskiej, jak już to zilustrowały powyższe przykłady. Ale ponieważ data zapisywana jest zasadniczo po łacinie, więc niekiedy przy cyfrze pojawiają się końcówki łacińskich liczebników porządkowych:

- $\quad$ die> 1ma 8bris A 1741 w Porycku CzacMH9, 58, Z Lublina <die> 1ma Novembris $1735 A^{\circ}$ BorW4, 8, z puttuska 1ma 8bris 1704 PotStefI3, 22 (łac. primus, -a, -um 'pierwszy, -a, -e');

\footnotetext{
16 Zob. Stownik geograficzny Królestwa Polskiego i innych krajów stowiańskich, t. 1-5, red F. Sulimierski, B. Chlebowski, W. Walewski, Warszawa 1880-1902.
} 
- z Brzezan 2da feb 1706 PotJ2, 16 (łac. secundus, -a, -um 'drugi, -a, -e');

- 3tia Aprilis 1728. z Kustyna StecKS4, 56 (łac. tertius, -a, -um 'trzeci, -a, -e');

- Z Porycka <die> 4ta 9bris $A^{\circ} 1740$ CzacMH6, 46 (łac. quartus, -a, -um, 'czwarty, -a, e');

- we Lwowie < die> 5ta Augusti 1705 HumS3, 18 (łac. quintus, -a, -um 'piąty, -a, -e');

- $\quad w$ Lazninie 6ta Iulij 1738 WorJóz5, 6 (łac. sextus, -a, -um 'szósty, -a, -e');

- $\quad w$ Lwowie < die> $7^{\mathrm{a}}$ febr 1759 anno AugJS5 (łac. septimus, - $a$, -um 'siódmy, -a, -e');

- w Eazninie 8va Februarij 1738 WorJóz3, 3 (łac. octavus, -a, -um 'ósmy, -a, -e');

- $\quad$ Porycku <die> 10ma xbris Ao 1740 CzacMH8, 49 (łac. decimus, - a, -um 'dziesiąty, -a, e');

- <die> 11ma augusti 1767 PodB1, 1 (łac. undecimus, -a, -um 'jedenasty, -a, -e');

- <die>18va 7bris 1737 mo $A^{\circ}$ CzacMH5, 31 (łac. duodevicesimus, - a, -um 'osiemnasty, -a, e').

Nazwy miesięcy mają niemal zawsze postać łacińską (albo spolonizowaną, albo oryginalną), użytą w dopełniaczu. Nazwy miesięcy od stycznia do sierpnia zapisywane są słownie, w całości lub skrótem:

- styczeń: $w$ Lwowie <die> 22 Januarij $1758^{\circ}$ AugJS4, 7, < die> 6 Januarii 1770 z Preszowa PotIg4, 5, Ze Lwowa <die> 17 Ianua 1723 HumS6, 69, 11 Ianua: 1719 w Lasczowie LaszAM9, z Brzezan 12 Janu 1706 PotJ4, 27 (łac. Ianuarius, Ianuarii 'styczeń, stycznia');

- luty: $A^{\circ} 1753$ <ie> 26 februarij CzetwM4, 8, 15 Februa: 1713 we Lwowie LaszAM5, 22, $w$ Lwowie $<$ die $>7^{a}$ febr 1759 anno AugJS5, $w$ Lwowie <die> 11 febr 1761 AugJS8, <die> 13 Febr 1770 z korszowa PodB2, z Brzezan 2 da feb 1706 PotJ2, 16 (Februarius, Februarii 'luty, lutego');

- marzec: $w$ Knerucie 1737 <ie> 1 Martij BorW5, 11, <die> 13 Marty 1770 PodB3, 35, <die> 26. Marty 1737 w Zułkwi PotJóz5, $A^{\circ} 1753$ <die> 6 marcij CzetwM5 (Martius, Martii 'marzec, marca');

- kwiecień: Z norynska <die> 6 Aprilis 1713 NiemA, 1, z Waręza 22 aprilis 1745 ŁaszJA6, 125, w Zbarazu 2 Aprilis 1716 PotJóz3, 36 (łac. Aprilis, Aprilis 'kwiecień, kwietnia');

- maj: W Katuszowie < die> 18 May 1704 HumS2, 13, W Lubieniach 15 May 1711 HumS4, 23, <die> 12 May 1770 z korszowa PodB4, 36 (łac. Maius, Maii 'maj, maja');

- czerwiec: we lwowie 13 Juny 1708 PotJ7, 86, 16 Iuny $74 A^{\circ}$ Z Zwanczy$k a$ LipKJ3, 270, <die> 8. Iuny $82 a^{\circ}$ z Zwan. LipKJ6, w Borszczowicach $<$ die $>23$ Juny 1761 PotJoach9, 15, w Lublinie 18 Iunij 1713 PotStefI5, 
28, D. 23 Junii 1777 w Podhorcach RzewSJ2, 22 (łac. Iunius, Iunii 'czerwiec, czerwca');

- lipiec: Leopoli d<ie> 10 July 1757 AugJS3, 5, w Bakunczycach 3 July 1700 ŁaszAM1, 4 (łac. Iulius, Iulii 'lipiec, lipca');

- sierpień: 1763 <die> 13 Augusti z Lublina BejzP2, 5, 1 Augusti 1777 W Porycku CzacSz8, $W$ Łaszczowie <die> 18 Augusti 1720 ŁaszJA3, 13 (łac. Augustus, Augusti 'sierpień, sierpnia').

Nazwy miesięcy od września do grudnia zapisywane są z zastosowaniem kombinacji cyfrowo-słownej:

- wrzesień: 17 7bris 1712 w Lasczowie LaszAM4; $w$ Borszczowicach $<$ die $>$ 29 7bris 1750 PotJoach1, 2; w Borszczowicach <die> 207 bris 1760 PotJoach8 (łac. September, Septembris 'wrzesień, września');

- październik: $1761<$ die> 11 8bris Z Lublina BejzP1, 3, 1ma 8bris $A^{\circ} 1741$ w Porycku CzacMH9, 58, <die> 17 8br 1751 w rososzu RzewMJ2, 34 (łac. October, Octobris 'październik, października');

- listopad: $A^{\circ} 1749$ <die> 2 9bris ze Lwowa CzetwM1, 2, we lwowie 30 9bris 1707 PotJ5, 50, w Buczaczu 12 9bris 1762 PotMB7, 104 (łac. November, Novembris 'listopad, listopada');

- grudzień: Leopoli <die> 11 Xbris 1747 AugJS1, 2, Leopoli <die> 15. Xbris 1756 AugJS2, w Łaszczowie 12 Xbris 1708 ŁaszAM3 (łac. December, Decembris 'grudzień, grudnia').

Stosowane skróty nawiązywały do nazw miesięcy w kalendarzu rzymskim, w którym pierwotnie rok liczył dziesięc miesięcy i zaczynał się od marca, a w związku z tym wrzesień był miesiącem siódmym, październik ósmym itd.

Polskie nazwy miesięcy stosowane były w analizowanej epistolografii rzadko:

- kwiecień: 13 kwietnia 1752 w krystynopolu PotFS6, <die> 29. Kwietnia 1782. Roku z Krupy PopJ1;

- maj $^{17}: w$ sięniawie < die> 16 maia 1721 PotJ9,16, 24 Maja 1751 w Zatoscach PotFS2;

- czerwiec: 4 czerwca 1751 w tartakowie PotFS3, 5;

- wrzesień: <die> 19. Września 1782. Roku Z Warkowicz PopJ2, 143v;

- listopad: <die> 28 Listopada $R^{u} 92$ Zwańczyk LipA, 123;

- grudzień: w Porycku D. ${ }^{a} 18$ Grud. 1734 Roku CzacMH1, 8.

Data roczna zapisywana była niemal zawsze w całości, czego dowodzą przytoczone wyżej przykłady. Okazjonalnie trafiają się zapisy zawierające tylko dwie ostatnie cyfry daty rocznej, np. <die $>28$ Listopada $R^{u} \mathbf{9 2}$, Zwańczyk LipA, 123, D 31 8br 95 Ru WorJóza9, 72.

17 Nazwa maj nie jest, oczywiście, nazwą polską, wywodzi się z łaciny (łac. Maius), w przeciwieństwie jednak do wszystkich innych nazw łacińskich, o których była mowa wcześniej, ta nazwa przyjęła się i zaadaptowała w polszczyźnie. 
Przy informacji o roku pojawia się łacińska forma anno 'w roku' (od łac. annus, anni 'rok, roku') zapisana w całości lub przy użyciu skrótu, najczęściej $A^{o}$, sporadycznie An.: <die> 26. Maji Anno 1770 z Hotuzyi KonAd, <die> 149 bris $1716 \boldsymbol{A}^{\circ}$ PotStan5, Z Lublina $<$ die $>1$ ma Novembris $1735 \boldsymbol{A}^{\circ}$ BorW4, 8, $\boldsymbol{A}^{\circ} 1753$ $<$ die $>6$ marcij CzetwM5, <die> 20 Iuny $1767 \boldsymbol{A}^{\circ}$ z Zytomierza NiemM, <die> 12 Aprilis an. 1729 z Sarawki WorPS1, 12. Niekiedy skrót sygnalizowany jest wyłącznie poprzez umieszczenie litery $o \mathrm{w}$ górnej frakcji pisma tuż po cyfrze oznaczającej rok: $w$ Lwowie <die> 22 Januarij $1758^{\circ}$ AugJS4, 7. Rzadkością jest użycie polskiego rzeczownika rok, również w całości lub w postaci skrótu: $<$ die> 29. Kwietnia 1782. Roku $z$ Krupy PopJ1, 140, <die> 28 Listopada $\boldsymbol{R}^{u} 92$ Zwańczyk LipA, 123, D. 11 8bri R 1764 WorJad9, 97.

Sposób zapisywania dat w epistolografii osiemnastowiecznej świadczy o bardzo silnych wpływach łacińskich, które zaznaczały się wówczas w polszczyźnie ${ }^{18}$.

\section{PODSUMOWANIE}

Formuła spacjalno-temporalna jako jeden z podstawowych i uniwersalnych wyznaczników gatunkowych listu stanowiła obligatoryjny składnik tekstów epistolarnych w XVIII wieku. Odgrywała zasadniczą rolę w procesie komunikacyjnym - zawarte w niej informacje faktograficzne pozwalały na zrekonstruowanie okoliczności, w jakich powstawał list, budowały wiarygodność przekazu, tworzyły wspólne „tu” i ,teraz” nadawcy i odbiorcy. Ponadto ze względu na swoje usytuowanie w granicznych, ramowych częściach listu (zazwyczaj w zakończeniu, rzadziej na początku, zawsze jednak w miejscu ściśle określonym, odrębnym i zarezerwowanym właśnie dla niej) stawała się wyznacznikiem delimitacji tekstu.

Sposób ujęcia i zapisu elementów faktograficznych w badanym zasobie epistolarnym odzwierciedla zwyczaje językowe XVIII wieku. Znamienną cechą jest finalne usytuowanie formuły lokalizacyjno-temporalnej. Zawartość treściowa obejmuje nazwę miejscowości oraz dokładną datę, ale zdarzają się formuły niepełne, pozbawione toponimu albo przeciwnie - wzbogacone o dodatkowe szczegóły faktograficzne, dotyczące zwykle momentu czasowego.

\footnotetext{
18 Warto wspomnieć, że łacińskie nazwy miesięcy funkcjonowały już w staropolszczyźnie. System polskich nazw miesięcy pozostawał jeszcze wówczas nieustabilizowany i liczył około 50 równolegle używanych jednostek leksykalnych różnego pochodzenia: rodzimych (prasłowiańskich i polskich), czeskich, niemieckich, łacińskich i hebrajskich. Wykrystalizowanie się nowoczesnego kalendarza miesięcznego nastąpiło w XVI wieku. Oprócz nazw marzec i maj, wywodzących się z łaciny, wszystkie pozostałe nazwy miesięcy w języku polskim mają charakter rodzimy. Zob. M. Borejszo, Staropolskie nazwy miesięcy, „Slavia Occidentalis” 46/47 (1989/1990), s. 19-31.
} 
Sposób zapisu danych zawartych w formule wykazuje znaczące wpływy języka łacińskiego na polszczyznę, co przejawia się w sposobie zapisywania daty (łacińskie określenia datum, die, anno, łacińska końcówka przy liczebniku porządkowym oznaczającym dzień miesiąca, łacińskie nazwy miesięcy).

\section{WYKAZ STOSOWANYCH ZNAKÓW}

[ ] - odczytanie niepewne

$<>-$ uzupełnienie skrótu

\section{BIBLIOGRAFIA}

Borejszo Maria. (1989/1990) 1991. Staropolskie nazwy miesięcy. „Slavia Occidentalis” t. 46/47: 19-31.

Całek Anita. 2019. Nowa teoria listu. Bibliotheca Iagellonica. Fontes et studia t. 34. Kraków: Księgarnia Akademicka.

Cybulski Marek. 2003. Obyczaje językowe dawnych Polaków. Formuly werbalne w dobie średniopolskiej. Łódź: Wydawnictwo Uniwersytetu Łódzkiego.

Data Katarzyna. 1989. Struktura tekstu listowego. „Język Polski” 69 z. 3-5: 142-152.

Kałkowska Anna. 1982. Struktura sktadniowa listu. Prace Instytutu Języka Polskiego 47. Wrocław: Zakład Narodowy im. Ossolińskich - Wydawnictwo Polskiej Akademii Nauk.

Książek Elżbieta. 2008. Tekst epistolarny $w$ świetle etykiety językowej. Prace Monograficzne Akademii Pedagogicznej im. KEN w Krakowie nr 478. Kraków: Wydawnictwo Naukowe Akademii Pedagogicznej.

Lalewicz Janusz. 1975. Komunikacja językowa i literatura, Wrocław-Warszawa-Kraków-Gdańsk: Zakład Narodowy im. Ossolińskich.

Maliszewski Kazimierz. 2001. Komunikacja społeczna w kulturze staropolskiej. Studia $z$ dziejów ksztaltowania się form i treści społecznego przekazu $w$ Rzeczypospolitej szlacheckiej. Torun: Wydawnictwo Uniwersytetu Mikołaja Kopernika.

Mroczek Katarzyna. 1978. Tytulatura $w$ korespondencji staropolskiej jako problem stosunku między nadawca a odbiorca. „Pamiętnik Literacki” 69 z. 2: 127-148.

Olma Marceli. 2006. Listy emigracyjne Józefa Ignacego Kraszewskiego do Władystawa Chodźkiewicza. Analiza pragmalingwistyczna. Kraków: Wydawnictwo Naukowe Akademii Pedagogicznej.

Pirożyński Jan. 1995. Z dziejów obiegu informacji w Europie XVI wieku. Nowiny z Polski w kolekcji Jana Jakuba Wicka w Zurychu z lat 1560-1587. „Zeszyty Naukowe UJ”, Prace Historyczne z. 115. Kraków: Uniwersytet Jagielloński.

Sicińska Katarzyna. 2013. Polszczyzna potudniowokresowa XVII i XVIII wieku (na podstawie epistolografii). Łódź: Wydawnictwo Uniwersytetu Łódzkiego.

Sicińska Katarzyna. 2016. „Pisanie”, ,, litera”, ,,gramota”... O nazwach listu w polszczyźnie XVII i XVIII wieku. W: W kręgu dawnej polszczyzny t. 2. Red. M. Mączyński, E. Horyń, E. Zmuda. Kraków: Akademia Ignatianum w Krakowie, Wydawnictwo WAM: 263-286. 
Sicińska Katarzyna. 2017. Formuły salutacyjne w korespondencji z terenu Kresów Poludniowo-Wschodnich (XVII-XVIII wiek). W: Zachowanie językowe - spontaniczność $i$ automatyzm. Red. M. Hawrysz, M. Uździcka, A. Wojciechowska. Zielona Góra: Oficyna Wydawnicza Uniwersytetu Zielonogórskiego (,Zielonogórskie Seminaria Językoznawcze" 2016): 225-249.

Sicińska Katarzyna. 2017. Formuły subskrypcji w korespondencji z terenu Kresów Poludniowo-Wschodnich (XVII-XVIII wiek). Cz. 1. W: Epistolografia w dawnej Rzeczypospolitej t. 7: Literatura, historia, język. Red. P. Borek, M. Olma. Kraków: Collegium Columbinum: 277-298.

Sicińska Katarzyna. 2019. Formuła wyrażania szacunku w strukturze osiemnastowiecznego listu polskiego. „LingVaria” 14 (2019) nr 2 (28): 107-119; https://doi.org/10.12797/ LV.14.2019.28.07; http://www.lingvaria.polonistyka.uj.edu.pl/documents/5768825/ 139218022/LV_28_e_book.pdf/0f2d3be3-53ac-4120-8842-6153daef0a5a.

Sicińska Katarzyna. 2020. Wierność, powinność, uniżoność i inne kategorie grzeczności językowej w finalnych formułach epistolarnych XVIII wieku. „Poznańskie Studia Polonistyczne. Seria Językoznawcza” 2020 t. 27 (47) nr 1: 163-183; DOI: 10.14746/ pspsj.2020.27.1.11; https://pressto.amu.edu.pl/index.php/pspsj/article/view/24583.

Skwarczyńska Stefania. 2006. Teoria listu. Oprac. E. Feliksiak, M. Leś. Białystok: Wydawnictwo Uniwersytetu w Białymstoku.

Sulimierski Filip, Chlebowski Bronisław, Walewski Władysław. Red. 1880-1902. Słownik geograficzny Królestwa Polskiego i innych krajów słowiańskich t. 1-15. Warszawa: Nakładem Filipa Sulimierskiego i Władysława Walewskiego.

Wołk Marcin. 1999. Tekst $w$ dwóch kontekstach. Narracja pierwszoosobowa w powieściach Kazimierza Brandysa. Toruń: Towarzystwo Naukowe w Toruniu. Uniwersytet Mikołaja Kopernika.

Żydek-Bednarczuk Urszula. 2005. Wprowadzenie do lingwistycznej analizy tekstu. Kraków: Universitas.

\section{LOCATIONAL AND TEMPORAL FORMULA IN THE 18TH CENTURY EPISTOLARY TEXTS}

Summary. The analysis deals with the locational and temporal formula present in the epistolary texts of the representatives of the nobility. That formula informs about the time and place in which the letter was written. Various forms of the formula are presented, varying according to its position in the structure of a letter and its content. The most important factor is the way in which the main components of the formula are written i.e. the toponym that indicates the place in which the letter was written (usually the toponym appears in the form of the prepositional expression in the locative with the preposition in or with) and the date (here one can observe a strong influence of Latin). Numerous functions of the locational and temporal formula were also discussed, such as defining the communicative situation, creating time and space community of the sender and the addressee, indicating text boundaries etc.

Key words: epistolography, locational and temporal formula, delimitation of the text, 18th century Polish 


\section{ЛОКАЛІЗАЦІЙНО-ТЕМПОРАЛЬНА ФОРМУЛА В ЕПІСТОЛЯРНИХ ТЕКСТАХ ХVIII СТ.}

Анотація. Предметом опису є локалізаційно-темпоральна формула, що інформує про місце й час написання листа і міститься в листуванні представників шляхетського стану XVIII століття. У статті розглядаються різні форми реалізації формули, а саме: iï позиція у структурі листа, зміст i, насамперед, спосіб написання основних компонентів формули, тобто топоніма, який вказує на місце написання листа (це зазвичай прийменниково-іменникові конструкції з прийменником $в$ або з і з іменником у місцевому відмінку) і дати (тут помітний сильний вплив латинської мови). Обговорено також численні функції локалізаційно-темпоральної формули, напр. визначення комунікативної ситуації, створення часово-просторової єдності відправника та одержувача, визначення меж тексту.

Ключові слова: епістолографія, локалізаційно-темпоральна формула, делімітація тексту, польська мова XVIII століття 